\title{
GENDER EQUITY IN BUSINESS SCHOOLS: What Has Been Promoted?
}

\section{EQUIDADE DE GÊNERO NAS ESCOLAS DE ADMINISTRAÇÃO: O Que Tem Sido Promovido?}

\author{
Caroline Rocha da Silva Galatoli \\ Escola Brasileira de Administração Pública e de Empresas/Fundação Getúlio Vargas \\ carolinegalatoli@gmail.com \\ Hélio Arthur Reis Irigaray \\ Escola Brasileira de Administração Pública e de Empresas/Fundação Getúlio Vargas \\ helio.irigaray@fgv.br
}

Submissão: $22 / 07 / 2017$

Aprovação: 13/11/2017

\begin{abstract}
The object of this research was to assess how gender discrimination is perceived by women students in Brazilian universities. It is expected that this paper can improve the gender equity discussion, specifically the glass ceiling phenomenon, exploring the gap between the women in university and those in job market. We have interviewed 33 female students of four universities in Rio de Janeiro. The interviews were transcribed and submitted to discourse analysis. We found out that discrimination occurs both by male professors and students, in classrooms, informal groups and university sports games. The reference model cited by interviewees from both universities have neutral characteristics in relation to gender typology academic described. This implies the beginning of a positive change of mindset, since previously jobs favored selection of male gender traits such as instrumentality. Instead, the interviewees value justice and ethics, for example. Considering that the educational environment reproduces society, managers should start concerning about what has been really promoted in business schools and why there is a gap between discourse and practices in those environments.
\end{abstract}

Keywords: Gender Equity, Discrimination, Feminism, Sexism. 


\section{RESUMO}

O objetivo deste trabalho foi de explorar de que maneira a discriminação por gênero é percebida por estudantes mulheres de universidades brasileiras. Espera-se contribuir o debate acerca da equidade de gênero, especificamente sobre o fenômeno de teto de vidro, explorando a lacuna entre as mulheres na universidade e as que ocupam o mercado de trabalho. Foram realizadas entrevistas com 33 estudantes universitárias de quatro universidades no Rio de Janeiro. As entrevistas foram transcritas e submetidas à análise de discurso. Foi evidenciado que a discriminação ocorre tanto por professores quanto alunos, dentro das salas de aula, grupos informais e jogos universitários. $\mathrm{O}$ modelo de referência citado pelas entrevistadas de ambas as universidades apresenta características neutras em relação a tipologia de gênero descrita na literatura. Isso implica no começo de uma mudança de paradigma, já que previamente o mercado de trabalho tem favorecido a seleção de atributos considerados masculinos como a instrumentalidade. Ao invés disso, os atributos valorizados pelas entrevistadas foram ética e justiça, por exemplo. Considerando que as universidades refletem a sociedade onde atuam, os gestores devem começar a se atentar ao que realmente é promovido nas escolas de administração, entendendo a lacuna entre o discurso e a realidade.

Palavras-chave: Equidade de gênero, Discriminação, Feminismo, Sexismo.

\section{INTRODUCTION}

The social affiliations inherited and traditionally attributed to individuals as definition of identity, such as race, gender, nationality and social class are more diluted (BAUMAN, 2005), and individualism is exacerbated as the Capitalism crystallizes as the predominant economic system (MARCUSE, 1973). Paradoxically, Capitalism has been responsible for making space for reflectiveness of the "I" (SILVA, 2006), through the structuring of collective movements of social and union resistance, which sought to establish the construction of collective identities based on the representation of the "we", which, dialectically, points to a differentiation of the "I". These collective political subjects workers, blacks, gays and women, which are the object of this study, were constructed on the basis of alterity; i.e, the construction of the "other" on the basis of the "I" (RICOEUR, 1991) and are present throughout the social corpus, including organizations. These, in turn, have been treated as in which individuals coexist in a functional and neutral objectives (IRIGARAY; FREITAS, 2011).

We understand that this functionalist ontological perspective neglects the fact that, in the workplace, psychographic segments, genres, ages and lifestyles, which, in order to survive, many Sometimes they shut up, hiding under the mantle of professional impersonality (IRIGARAY, 2008). In fact, in the field of Organizational Studies, diversity of the workforce has been analyzed from a single perspective: race or ethnicity (ALVES, GALEÃO-SILVA, 2004; FLEURY, 2000), physical disability (CUNHA, 2016), sexual orientation (IRIGARAY, 2008), obesity (PRINGLE, 1988.), mental disability (FOLEY, 1979) or gender (BETIOL, 2000).

As far as women are concerned, previous studies have suggested that, indeed, there is discrimination against gender in the workplace, and women are more prone to be harassed sexually and morally than men, they earn lower salaries than their male peers (ECCEL; GRISCI, 2011, as well as they face a glass ceiling which deters them from getting promoted (OLIVEIRA, 2014).

In the academic environment, though, the pattern has improved. In Brazilian universities, the female students, frequency is higher than male (IBGE, 2016); thus, we 
observe a promising scenery for the next decades. However, this fact by itself does not mean that patriarchate is not present in the high educational environment. As a matter of fact, during the school years, women students are discriminated against on the basis of gender, by their male peers, teachers and also by other women (IRIGARAY; PAIVA; GOLDSCHIMIT, 2017); Indeed, masculine hegemony is reproduced by both the oppressor and oppressed (ARENDT, 2007).

Nevertheless, there is still a gap in the literature: how is discrimination against gender perceived by female Brazilian university students? This is our research question.

In order to answer it we carried out an empirical qualitative research in Brazilian private and public universities, in Rio de Janeiro. This study has an autoethnographic approach, for one of the authors is a female student, besides it has also an ethnographic one, for the other author has been a professor for the past 20 years.

This article is divided in five sections, besides this introduction. In the next one, the second section, we will present our theoretical framework, in which we highlight the concepts of male hegemony and the social construction of feminine identity, the sociological construction of gender, and the feminist movement and gender equity in the workforce. Right after, in the third section, we will describe our methodological procedures; in the fourth, we will present and discuss our findings. In the fifth and last section, we present our conclusions.

\section{THE THEORETICAL FRAMEWORK}

\subsection{Male hegemony and the social construction of feminine identity}

Critical postmodernity has borrowed from Gramsci the Marxist concept of hegemony, or how the ruling class establishes - and maintains - its power and dominance over the proletariat. It consists of the persuasion of the majority of the population through the media, organizations and institutionalization of the concepts of "normal", "natural", and "common".

The notion of masculinity has been historically constructed and associated with values such as "courage", "autonomy", "ability", "adventure" and "group solidarity" (CARRIGAN; CORNELL; LEE, 2002, p.75). Thus, the concept of male hegemony lies upon the question of how heterosexual men are granted access to economic capital, privileged positions of wealth and power in the social corpus, and how they legitimately reproduce the social relations, which generate and ensure their domination.

Male hegemony is imposed by violence, often symbolic, soft, insensitive and invisible to the victims themselves (BOURDIEU, 2007), since it also generates pleasure and is perpetuated by purely symbolic means of communication and knowledge (FOUCAULT, 1994) or, more precisely, as Bourdieu (2007, p. 8) pointed out: recognition of, ultimately, the (con) feeling of their own victims. "The logic of male domination manifests itself and pervades all social relations, since it is exercised in the name of a symbolic principle, which is (re) known both dominated and dominated (BOURDIEU, 2007).

This androcentric power is exercised and evident in the language used in daily-life situations; in fact, the verbal and non-verbal communication; i.e, the way of speaking, expressions used, use of gender; the crystallization of the way of thinking (man must be more objective than the woman); the cult of the way of speaking (man must be quieter); the social expressions of specific lifestyles (clothing, male color and female) and, mainly, the control of the body (the males must be more contained, gesture less). Strictly speaking, androcentric power also manifests itself in practices sexual relations, since it establishes itself on the premise of the fundamental division between masculine (the active) and the feminine 
(passive). This principle "creates, organizes, expresses and directs the desire" (BOURDIEU, 2007, p.31).

On the one hand, there is the masculine desire for possession and domination eroticized; on the other, the feminine, which acquiesces to the desire for male domination, subjecting the woman to eroticized subordination. Thus, sexual relations become social relations, in which there is the eroticized recognition of domination.

The principle of inferiority and exclusion of women, ratified and extended through mythic-ritual system of society, is the fundamental dissymmetry established between men and women. As a matter of fact, in the field of symbolic exchanges, relations of production and reproduction of capital symbolic, whose central mechanism is the matrimonial market, the basis of the whole social order, women are seen as objects, symbols, whose meaning is whose function is to contribute to the perpetuation or increase of the symbolic androcentric capital (BOURDIEU, 2007), so the home becomes the antipode of work (TONELLI, 2001). Thus, women are educated in order to participate in the power by proxy, that is, through men (via marriage, for example) and are always placed in an external and subordinate position; they have as their primary function take care of the players: the men. This view was made explicit by Kant (1964, p.770), "women cannot personally defend their civil rights and affairs; as it is not for them to wage war: they can do so only through a representative."

This In this way, differential socialization predisposes men to love power games, and women to love the men who throw them; the masculine charisma is the charm of power, the seduction that the possession of power exerts on the bodies, whose own drives and whose desires are politically socialized (PRINGLE, 1988).

The construction of the feminine identity, sometimes, occurred on the confrontation irreconcilable masculine versus feminine, in which men are "the other" and, in spite of the feminist position, inadvertently subjugated women to the condition of "second sex" (BEAUVOIR, 1995). On other occasions, women did not accept that their sex, or their gender, were "second" and argued that the sexes or genders are two, without first or second (IRIGARAY, 1994). In fact, to discuss women and the feminine subjectivity of the point of political view means recognizing that they do not need (or want to) be "the other" (male subject), as Irigaray (1994, p. 53) asserted: "the question of the other is misplaced in the Western tradition, the other is always the other of the same, the other of the subject and not an other".

\subsection{The sociological construction of gender}

When analyzing the differences between men and women, it is important to distinguish two distinct categories: biological sex and gender itself. The former includes only the physiological part of human body, been determined on birth and not been able to change by natural procedures; the latter includes features established by society as a construct. Although the studies reveal there are no automatic relationship between biological sex and the prerogatives of a gender (COSER, 1989), the attempt of justifying masculine and feminine traits according to natural criteria had reinforced the gender inequality, thus resulting in many disruptive consequences, mainly in terms of social relations and sexual division of work.

Bourdieu defines gender as sexed habitus. Understanding this sociological concept as the way a group of individuals, who shares a similar cultural capital, think and acts (BOURDIEU; MICELI, 1974), the author perceives, just as the other kinds of habitus, that gender is imposed by social agents such as Work, Family and School, therefore the group of characteristics defining masculine and feminine are socially constructed. Finally, as a habitus, it is not possible to an individual to easily change from a type of habitus to another without 
retaliation from society, so this would explain why a more masculine woman or a feminine man can be so discriminated where they live.

Gender has been basically constructed on the reproductive function of women, resulting in distinct work division comparing to men, the providers. Bourdieu (2007) argues that men have been associated to the public space and the following personality traits: aggressiveness, competition, rationality, independence, and strength; whereas, women have been related to home and, historically, depicted as caring, cooperative, emotional, dependent, and fragile. Hence, the workforce desired attributes - and valued by the market - such as aggressiveness, competition and rationality are masculine (KIMMEL, 1994), what is a disadvantage per se for women.

\subsection{The feminist movement and gender equity in the workforce}

The gender attributes aforementioned described are reinforced by the named masculine hegemony (BOURDIEU, 2007). The masculine domination is a sociological process recognized by both the oppressor (men) and the oppressed (women), by the use of symbolical structures such as the way of speaking, thinking and acting (IRIGARAY, 2008). To confront this Weltanschauung is to challenge the society paradigm. In this sense, the twentieth-century feminist movements have struggled not only against the legal privileges reserved for men; but also against the patriarchal culture, moral codes, and values (ECCEL; GRISCI, 2011).

There are similarities in the multiple feminist movements in different countries, although the way a nation develops and reacts to it is distinct. In general, they all start with the legal equality, which means the right of vote work and be educated. Most of the Western countries have already consolidated these basic rights; nevertheless, in sexist societies women are still discriminated against based on gender, in micro-social interactions.

Furthermore, the feminist movements also embrace other parallel movements related to minorities that are also discriminated against, such as the blacks, (GUIMAR ÃES, 2003) gays, lesbian and bisexual individuals (IRIGARAY, 2008), as well as those physically or mentally handicapped. In fact, currently, these groups are confronting a violent neoconservative wave. For instance, in Brazil, the feminist philosopher Judith Butler was physically assaulted at Congonhas airport, in São Paulo, many Afro-Brazilian religious temples, which are called terreiros, have been attacked and set on fire by evangelicals; moreover, Brazil ranks in the top of the list where homo and bisexual individuals are attacked and murdered. Consequently, Brazilian women, who also share other discriminatory trait (black or lesbian, for instance), suffer second or third degree discrimination (IRIGARAY, 2008).

Either in terms of opportunity access, racial issues or sexual diversity debates, there is a propensity to set women as the secondary sex (BEAUVIOR, 1995). Therefore, the main objective of the current feminist movement is to promote the women' empowerment, covering all female groups (black and white, cis and transgender, from different political perspectives) reunited in the battle against patriarchate. It should not be seen as the opposite of sexism and misogyny.

In the workforce arena, organizations have become more heterogenic in the past decades. Changes on societies' structure are allowing the mutual living of different types of people, working together in the same space. Metrics, such as workers' performance, organizational environment, safety and well-being, tend to be better in companies that adopt diversity programs (IRIGARAY, 2008). 
Many studies try to apply the equity gender concept within organizations. Understanding gender equity as the equally valorization of genders, understanding their differences as complementary, many effects are formed on organizations that promote this perspective.

Organizations can provide a positive impact on the society by implementing meritocracy and economic benefits for the individuals. On the other hand, it is also shaped by the society they are. Thus, the organizations can reflect the different types of discrimination, being an instrument to reproduce them.

Although there are many advantages of gender equity, there is little knowledge about how practically implement the right policies in the companies. In legal terms, the feminist movement was responsible for many achievements regarding the women access to education and job market, enabling them to occupy the same duties as men, including politics and military career, previously restricted to male individuals (MARIUZZO, 2008), although the professions that demand more physical effort are still more occupied by men (HIRATA, 2002).

Analyzing the gender stratification on top levels of companies, something blocks women to achieve these positions. In Brazil, there are only $24 \%$ of female managers (GRANT THORNTON INTERNATIONAL BUSINESS REPORT, 2016). This invisible obstacle is conceptualized by Steil (1997) as the glass ceiling and since then has been studied by many researchers, even extending it for other minorities such as the handicapped (IRIGARAY; VERGARA, 2011).

For women, there are some reasons for the glass-ceiling phenomenon. First, the discrimination on workplace, by being heard different for being women (SANDBERG, 2013), besides by not representing the consolidated leadership model in most of the companies (ASKEHAVE; ZETHSEN, 2014). Furthermore, Eagly and Carli (2007) believe that there are even more complex barriers for women to be promoted and develop their career, representing not a glass ceiling, but a glass labyrinth. For example, they might have to decide whether or not embrace maternity, and the conflict between career and domestic role, since it is not equally shared with men.

Thus, studies regarding the glass ceiling/labyrinth should not only consider the organization discrimination, but also the option of the women to abdicate or not to rise. Most of papers suggest that, indeed, companies somehow promote obstacles for the women. One example is the teachers on public universities described by Miranda, Mafra and Cappelle (2012). As a public position, the glass ceiling should not occur, since admission and promotion should only be by technical parameters (e.g. number of publications, curriculum). However, there are the commissioned and elected vacancies such as the rectory and the head of department. For those positions, men are still more frequent, which suggests that even the career plan for the public education is gendered biased so the women cannot be promoted.

Considering education as a gateway to job market, and the major proportion of women rather than men in Brazilian universities, the focus of this paper is to explore to what extent gender discrimination occurs and is perceived by female Brazilian university students. This work represents a preliminary discussion about the glass ceiling in the first stages of the career of this segment of society.

\section{METHODOLOGICAL PROCEDURES}

This study was illuminated by the ontological perspective of critical postmodernity (BOJE, 2001), which analyzes society from a non-patriarchal perspective (BENHABIB, 1992), that is, the focus of discussion has shifted to other dimensions, democracy and 
multiplicity), starting from the premise that there are multiple voices, living multiple realities (GERGEN, 1991). This work is based on the assumption that the understanding of the meanings of social actions must start from the perspective of the subjects themselves, and not from the researcher's view (DaMATTA, 1979); in this sense, we sought to borrow the looks of the 33 female students, interviewed between March 2016 and September 2016. They were students of different social classes, races, sexual orientations, who only shared the same gender and the fact that were undergrad students in different Business Schools in Rio - two public university and four private schools, in Rio de Janeiro.

The reports were transcribed and submitted to discourse analysis, in order to understand the corpus of social interaction of the actants; i.e, the different participants involved in an action and who have an active or passive role in it (CHARAUDEAU; MAINGUENEAU, 2004).

Throughout this work, we were aware that this research strategy would not make us neutral or autonomous; however, we sought to maintain impartiality through the estrangement of the studied object (bracketing), that is, it followed the orientation of Bourdieu (2007) not to confuse the subjectivism of the researcher (his value judgments) with subjectivism of research objects (individuals, groups, socio-cultural systems). In this research, Goldenberg (2000) considerations were kept in mind, so a script compatible with the focused, semi-structured interview was chosen. Respondents were, a priori, informed of the purpose of the research, as well as guaranteed anonymity and confidentiality of their reports. The interview per se was structured in two parts: a) the collection of the categorical data of the interviewees (gender, age, marital status, age, schooling, training area, position and company) and b) a conversation about their life and career trajectories. (CAVEDON; FERRAZ, 2003), something that the historiography or the official reports made available in the written sources they were not able to capture, which allows the researcher to have a notion of the process of what he is investigating (BECKER, 1994).

Life stories are composed of disconnected fragments (antenarrative and chaotic narratives), which are often inconsistent and ambiguous, but irrefutably contribute to the comprehension of the whole (VICKERS, 2005; DEBERT, 1986). Bourdieu (2007) also corroborates the idea that through life stories researchers can access social structures and their functioning, for the narratives of more personal difficulties, of tensions and contradictions, in more strictly subjective appearances, express the structures of the social world and its contradictions.

This conception of practical analytical devices (BOURDIEU, 2007, p. 236) was extremely useful in the data analysis carried out, as one of the interviewees stated: "people live in a zone of social conflicts and contradictions." Practical analyzing devices are individuals occupying unstable positions (roles of mother, woman and boss, for example), in which social structures are at work and, because of this fact, driven by their contradictions, are forced, to live or survive, to practice a form of self-analysis which often gives access to the objective contradictions of which they are victims and to the structures that express themselves through them.

The meetings were held in public places, although all the conversations were private. They had an average duration of 75 minutes. The conversations, as well as the field notes made before, during and after each meeting, were transcribed, which generated a document of 157 A4 pages, typed in Times New Roman font, size 12, single spacing. These data were submitted to discourse analysis, a method that aims not only to capture the message, but also to explore its meaning, its meanings: what is spoken and how it is spoken, what is explicit and what is implicit, the language used in discourse and emphasized dimensions (PUTNAM; FAIRHURST, 2001). Specifically, in this research, discourse analysis was used as the study of real language use, by real speakers, in real situations, and language considered as an 
activity anchored in a context, therefore capable of producing transphrastic units (DIJK, 1993). By definition, transphrastic units are the result of a process of constitution of texts from the combination of phrases (STATI, 1990) and their analysis makes it possible to show the use of language as social, expressive and referential purposes (SCHIFFRIN, 1994). Given the volume of text resulting from transcripts and field annotations, the suggestions of Santos (2002) were used to use Atlas / TI software to analyze the data collected.

As the field saturated (the answers were repeated) we identified seven emerging categories: diversity, homophobia, feminist movement, student sexism, professoral sexism, reference model and university games.

\section{FINDINGS AND DISCUSSION}

\subsection{How does discrimination occur?}

Considering not only the interviews, but also the experiences and situations that one of the authors has lived and witnessed, throughout her life as a student in an ivy-league business school, we found that there are strong evidences that women undergo both explicit and implicit discrimination against gender from their male peers, professors and, curiously, from other female students.

In a first moment, it was difficult for interviewees to report sexism inside classroom, specifically. Actually, most of the cases occurred in the corridor, social groups and extracurricular activities as the university games, which are discussed in a next section of this paper.

It is not true that discrimination does not occur, though. But in the academic environment, the sexists, homophobic and racist students tend to restrain their opinions, thoughts and behavior, through impression management (IRIGARAY, 2008).

The most severe explicit sexist discrimination was reported by an interviewee, named Kate. She told us that she had been verbally assaulted, in her Facebook profile, by a male classmate. He had offended her to her feminist and political positions, using sexist violent arguments. As Kate confronted her aggressor in the classroom, in an ivy-league private school, the (male) professor supported her, and reprimanded the male students who, as a group, were defending the attack. The boy in question justified his actions and reacted to the professor's argument saying that he was a man too; thus, he should align with the boys; besides, the comments were made in his private computer, so the school had nothing to do with it. This situation revealed that men, even those of psychodemographic traits, different tend to - at least, attempt - to defend each other (and themselves) as a homogeneous group. Indeed, the fact that the professor stood by the female student was a shock for the boys. Moreover, these students do perceive a cleavage between their school and private lives; as if what they do out of the academic walls had nothing to do with their evaluation in the classroom.

Notwithstanding, as Orwell stated in this book, "Animal Farm", our interviewees have also found out that all women are equal; however, some are more equal than others are.

Indeed, many men have expressed discriminatory attitudes towards women in general; nevertheless, they tend to be more vicious against those who are considered aesthetically unattractive, poor, old, homosexual, and/or from another race than "white"; i.e, blacks, native Brazilians or Asians.

These secondary traits have also served as basis for discrimination for "mainstream" women. Although one could expect some degree of solidarity amongst the minority groups, this empirical research has revealed that some women do discriminated against other against 
physical appearance, age, and social status. Ironically, some do also reproduce sexist arguments and jokes. In fact, humor turned out to be one of the strongest means to reify sexism. Our interviewees have systematically affirmed that jokes on how women drive, that they were not fit for Finance classes, and that they have engaged in a business school just for "husband shopping", are recurrent.

Discriminatory remarks came not only students, but also from professors, who should be fighting against them. For instance, Isabel heard from a Marketing professor at a public university: "it does not surprise me that women nowadays do not achieve higher positions in business administration. Because you certainly have difficult to decide things. Yes, decision making process is hard for women"._The underlined lexical selections reveal that this man has deeply incrusted the personality traits depicted by Bourdieu (2007).

Moreover, as quick and efficient decision-making is fundamental in the corporate world, this professor is justifying and naturalizing the glass ceiling. The same train of thought has been followed by a professor in a private school, which targets at low-middle-class students: "I don't know what you (girls) are doing here. You should be taking Human Resources. The Finance world is tough. You have to be bold, right boys?"

Second-degree discrimination has also been observed in a discourse fragment extracted from a religious ivy-league university's Marketing professor's lecture. According to one of our interviewees he has stated that: "I don't get it. She is a woman already. Why does she have to be a lesbian too? This is sick. I think these people are freaks". The lexical fragments "already" and "too", in this derogatory speech, denote that the girl's sexual orientation aggravates her inferiority for her gender.

Discrimination is also reified through (would-be) physical and verbal attacks. For instance, Isabelle told us that there was a student at her school that would pretend to slap me the girls on the face, pull their hair, and simulate a sexual intercourse. As she reprimanded him and demanded that he stopped, he said that: I do this with all my female friends as a normal thing. I thought you would be OK with that". This comment and this kind of behavior reveal the naturalization of women being seen as objects to masculine desires and dominance. Besides, many women do not confront their aggressors and nothing is being done neither by the schools nor the students.

Another sexist form of discrimination, noticed on private university, is the physical appearance. Besides the dress code, Britney has reported that she became a target when she had a short hair. She told us that: "people said that men do not like short hair, and that women are ugly if they have it, that we should follow a stereotype. Both men and women had said that to me". In this discourse fragment, it became evident that that there is not, necessarily, solidarity among women; for, when it came to discriminate against someone for her physical appearance, some girls aligned with the boys. This may have happened because Britney was homosexual, dark-skinned or poorer than the other students were. In fact, one of these other traits prevailed over her gender and made her victim of second, third, or even, fourth-degree discrimination. These classmates argued that it was against the stereotype of female beauty according to her colleagues that support that she should use a long hair to pleasure men.

The same thing was also exposed by Anne, who not only does not follow the pattern in this sense, but also because she is an assumed homosexual. According to Barbieri (1991), by trying to control a woman's body, it is actually aimed to control the women herself and establishing her position in society, subrogating her to an erotic object for man.

Discrimination practiced by teachers was noticed only in the public university, for example as the report of Isabelle. Considering the important function of the professor for the formation of the students, besides the fact that is more difficult to fire an employee in public sector rather than private, there should be a special concern about sexist practiced by them. The students' responses to this act vary: some of them contest; some of them keep in silence. 
The impact of this form of prejudice of female students suffer is measureless, but the influence on the spread of discrimination is quite obvious. In this sense, social pressure on classrooms that has more knowledge about these questions might inhibit or reject those teachers' acts.

Jane's report about a physical and moral violence suffered continuously in the corridors of her public university is twofold. First, her colleague considers this behavior as a normal act, subordinating his other friends to the same situation and expressing a masculine domination (BOURDIEU, 2007). Beyond that, knowing she is bisexual, it is possible that he sees her as a fetish to pleasure his impulses, associating homosexuality and bisexuality as profligacy.

This was also said by Anne, who has a serious and long relationship with a girl, but is not perceived in the same way heterosexual is perceived when dating someone. According to Irigaray (2008), the reaction by LGBT people to discriminatory acts in the workplace are divided into three categories. The totally assumed ones might adopt strategies of "gladiators" or "pacifiers"; the partial assumed may express "kindles" or "strength"; finally the not assumed divides in "chauvinists stereotypes", "seductive" or "invisible" (IRIGARAY, 2008, p. 88, translation by the author). In this sense, while Jane adopts the "gladiator" strategy, Anne seems to adopt a more "pacifier" position.

\subsection{How is the feminist movement perceived?}

In a common sense, the feminist movement is perceived positively by all interviewees. Equality was the most cited characteristics, thus the main function according to them is to promote women freedom to the patriarchal society.

The existence of the collective group of women in both universities, promoting debates of the function of women and female empowerment, is valued differently by them. For the private university, it is a very small group and perceived badly as a reactionary team that tries to impose discussion on an aggressive way, such as hanging posters and balloons pro abortion.

On the other hand, the collective group in the public university analyzed is most known by all courses, being divided into other similar groups reuniting girls of a same course such as business administration or biology. The interviewees had reported that recently it was created the Economy Collective Group of Women, which was rejected and mocked by men, suggesting that this course might be more sexist than administration. Therefore, women from public university seem to be committed to the feminist movement.

Another interesting perspective was the association of the movement as something related to left parties (DELPHY, 1994; COSTA, 2014). In Brazil, this kind of political party had in the past years expressed more support to this type of movement, besides other minorities such as LGBT and black people groups.

Right now, Brazil is intensively polarized in terms of political positioning, representing an unstable period composed by an close dispute during the last election, followed by an impeachment process and corruption accusations by many politicians, though mainly by left parties such as the Workers' Party. Therefore, not judging the merit of any process, the fact of associating feminist movement with a political movement, specifically party-orientated, in an unstable period that Brazil is dealing with, may retard the achievements it promotes.

Last but not least, the role of men in the movement was questioned. The interviewees suggested they may be important actors, though controversial, representing the academic 
debate about the complex and contest function of men in the feminist movement (BAILY, 2015).

On one hand, the female freedom for gender stereotypes might has similar effect to the male gender, releasing it from the concepts that suppress men to express emotions in public, or concepts that subjects them to more risky situations. On the other hand, there is intense debate about whether and how can they contribute to the movement (BAILY, 2015) since the feminism exists as a reaction to oppression from men to women in a patriarchal society. Institutions such as the United Nations and European Union support the role of men promoting gender equality (EUROPEAN INSTITUTE FOR GENDER EQUALITY, 2012; UNITED NATIONS, 2004), but are criticized by not positing women in the front of the lectures and debates. In other words, a man lecturing about feminism is more accepted by society than a woman is, thus it could be more effective; however oppressing women on the formulation of ideas might be portrayal of androcentrism, which women try to fight against.

In fact, for most of our interviewees, "feminism is about gender equity, not equality, but we should accept the differences in order to promote that both genders coexist equally". The terms equity and equality are, sometimes, used interchangeably, which can lead to confusion because while these concepts are related, there are also important distinctions between them. Equity, as we have seen, involves trying to understand and give people what they need to enjoy full, healthy lives. Equality, in contrast, aims to ensure that everyone gets the same things in order to enjoy full, healthy lives. Like equity, equality aims to promote fairness and justice, but it can only work if everyone starts from the same place and needs the same things.

We also found out that the politics do play an important role in these students' lives. For instance, Anne stated that: "I would like to emphasize that I am not left orientated, in a political perspective. I think when you say that you are feminist, everyone immediately thinks you are related to left parties". It was clear for us that the political division that has split the country in the recent years has made that feminism be mistaken by leftism; therefore, some students argued that there the discrimination was not only against gender, but also a would-be political position.

The bottom line is that, as stated by Isabelle, "the feminist movement for me means a lot of freedom in many aspects. It makes me understand who I am, who I can be, what can I achieve and what restricts me, and also what is my duty inside the movement as well"; i.e, these students fight against the mercantilization of the female body.

\subsection{The university sport games}

A good example is what has happened in the university sport games. In fact, there are many reports had included the university games as improvers of sexism inside their universities, both private and public. First of all, the female participation on the organization of events and teams is reduced, which suggests that women do not feel comfortable in being part of. Specifically in the public university, where the organizations are quite older, there are some songs which lyrics show discriminatory and offensive content not only to women, but to other minorities such as LGBT group. In this sense, the girls have attempt to chance it many times, but are constantly suppressed by men, generating a vicious cycle in which the spread of sexism inhibit female presence, and having less women it is a tend to maintain the status quo, such as the lyrics, jokes and disrespect during the games.

In the private university, the students' sport association has cheerleaders. Britney reports that they are all women, who also are responsible for reproducing homophobia by publicizing that a man cannot assist them in the team, otherwise it would be too feminine for 
them. She told an episode in which a group of male students had accepted being part of a training that required more strength, but they did not continue because they did not wanted other men to realize they were part of a group dominated by women.

Sports spaces are frequently described as masculine and heterosexist environments (WALKER; MELTON, 2015), and in university sports this is also a pattern. Therefore, besides reflecting the characteristics of a society, the university is responsible to spreading its wrong ideals about it. The sports pedagogy, which is mostly related to primary and high school, can be applied to higher education, trying to promote the university sport in an inclusive and transformational instrument (MACHADO; GALATTI; PAED, 2015).

For example, in the United States, it is very common to offer scholarships to athletes, and this model could be applied to Brazil aiming to achieve better social inclusion. In the private university analyzed in this paper, the sport has been supported by the coordinators of the courses, though it is quite new.

In this semester, there is one female student in an international competition, and she is been supported, in terms of prestige, by the both the sports association of students and the directors. This kind of recognition may foment the social function of sports; specifically the fact of the student is a woman might increase the female empowerment within this university. At the same time, it can help achieving the educational objectives settled by the coordination, aiming the development of students in terms of personal aspects and character of relations (MACHADO; GALATTI; PAED, 2015).

\subsection{The reference model for female students}

In this research, we have found out that there is a reference model for female students. The question about the feminine model of reference where progressive: even those who had cited their mothers did not choose it due to stereotypes such as domestic roles or physical attributes, but the financial independence from their husbands and perseverance in achieving their goals. Neutral characteristics, not suggestive of a specific gender, describes their ideal feminine model, previously described by many women by stereotypes that reinforced, by that time, the values of society.

Other interviewees used as a reference female teachers or students that stand out by their personalities, raising their voice, being direct or rational. In this case, the model approximates of a typology more masculine, in comparison to the characteristics described by Bourdieu (2007) and displayed in Table 1.

These results can be explored according to the Role Congruity Theory of prejudice: "A potential for prejudice exists when social perceivers hold a stereotype about a social group that is incongruent with the attributes that are thought to be required for success in certain classes of social roles" (EAGLY; KARAU, 2002, p. 2).

Following the modernization of social relations and women ascension on higher education and job market, besides it is a slow process, the paradigm that links women to domestic role, caring and sensitiveness (BILLING; ALVESSON, 2000), while binds men to competitiveness, aggressive and rationality (KIMMEL, 1994), is being progressively disrupted. Therefore, the reference model pointed by the interviewees does not display, necessary, a stereotype, but represent women as neutral or with a few masculine characteristics. Finally, this works does not fit accordingly to Broverman et al. (1972) who had verified that university female students tended to associate men to instrumental traits and women to expressive characteristics. 


\subsection{How can universities contribute for the deconstruction of sexism?}

What is the role of the universities in terms of fighting gender discrimination and its consequences? The interviewees' opinions diverge. On one hand, Anne believes teachers should not express their opinions so easily, fearing that it might display a political bias. Britney perceives omission as a gap to worse situations, such as the propagation of a rape culture. In parallel, considering that students has already got some cultural background before entering higher education, would it be more effective to promote gender equity before university, on primary and high school?

Although people understand the function of university on the technical formation of individuals, it should also be considered the personal formation. The students tend to unite themselves in groups that share same interests, which explains the formation of Collective Group of Women, Collective LGBT group and other groups that not only points out some issues on university debates, but also welcome students that belongs to minorities in the university environment. In this sense, the coordination of courses should be partners with them, assisting their discussions aiming to the personal development of the students.

Besides, promoting debates, classes and lectures about gender equity is a crucial point. In practical terms, a possible suggestion would be to foment university extension as a social and transformational movement. According to Cerqueira (2015), the Brazilian university has always been representative of a social and historical context, being represented by different social structures, while specifically the university extension on Latin America is related to social movements.

Therefore, the spontaneous and simultaneous arising of different Collective groups within the university should be reinforced in a structured and effective way.

\subsection{Prescriptions for job market}

Bearing that in mind, would there be prescriptions for the job market? The majority of interviewees had not yet explored the job market, but provides some clues about what they expect to their careers. Isabelle suggests that in business administration women are more represented in areas as the Human Resources and marketing, rather than finances and project management. This is also related to the sexist speech of her teacher, who points out that women would have difficulty in the decision making process. After all, what is the glass ceiling that forbids then to occupy positions that request more analytical or mathematical knowledge?

Marra and Bogue (2006) realized a longitudinal survey with female engineering students in the United States. They verified that the self-conscience rates have been increasing, but there are not yet evidences for correlation with graduation, GPA (grade point average) and participation on engineering activities. Hawks and Spade (1998), in turn, suggest that specifically during the first years of higher education the women tend to compare themselves with male students, judging in a worse way than the men criticizes themselves, thus this represent one barrier for finishing the course. Therefore, self-conscience might be one of the glass ceiling components, making it more difficult for women to achieve, on the business administration field, positions as finances or leadership.

Isabelle reports another issue about recruitment and selection process favoring male admission. Not because they are women as a biological sex, but because of their gender, women are not incentivized to project themselves and show their point of view. Askehave and Zethsen (2014) verified that Danish job advertisements are biased, since most of the desired characteristics are associated with male traits by the candidates of both sexes. Hence, 
deliberately or not, companies are selecting masculine characteristics to enter the organization, increasing the glass ceiling and prejudicing women to enter the job market.

A possible solution to interrupt this cycle is to start valuing neutral attributes, so it can be assigned for any gender. According to the reference model of most of the interviewees, the companies should look for characteristics such as justice, technical competence and ethics. Furthermore, since Brazil is current dealing with corruption scandals, seeking ethics at workplace should have a positive impact independently the employee sex. In this context, a new leadership concept arises, known as authentic leadership (Walumbwa et al., 2008).

Authentic leadership is defined as the "pattern of leader behavior that draws upon and promotes both positive psychological capacities and a positive ethical climate to foster greater self-awareness, an internalized moral perspective, balanced processing of information and relational transparency on the part of leaders working with followers, fostering selfdevelopment" (Walumbwa et al., 2008). This concept might be the key for organizational change into a new paradigm, in which an ethical and consistent leadership model can be used as an example for the spread of values upon all over the organizational structure. Casoinic et al. (2015) suggest that Brazilian leaders had started expressing characteristics of authentic leadership, such as self-awareness, relational transparency, internalized moral perspective and balanced processing of information, although leaders might be expressing impression management for their followers.

\section{CONCLUSION}

This paper aims to contribute to gender studies, which debate has been fomented by international institutions such as United Nations and European Union. The global goal to reduce gender inequality as a way to promote human development and poverty reduction should focus not only in studies about job market, but also regarding the university environment, for being a place for both technical and personal formation of individuals.

Specifically for Human Resources Management studies, the knowledge about culture and society should also consider in what ways gender and diversity affect individuals' values and attitudes. Even though nowadays women represent more than 57\% of universities vacancies (IBGE, 2016), diversity still follows a dominant class pattern in Brazilian society, with predominance of white and upper classes, reflecting a inequality in terms of access of opportunities.

The gender discrimination is hidden inside academic environment, being expressed more outside than inside classrooms, for example in university games, informal groups and events. This suggests that people are gradually acquiring consciousness about the prejudice of discriminatory acts, although it will take longer to change the mindset in order to extinguish all kinds of prejudice. When analyzing the reference model for the interviewees, it is noticed that a subtle paradigm change has started, in which women are no longer been referred by their domestic roles or stereotypes, but for neutral gender characteristics such as justice, independence and perseverance. Nevertheless, the job market still values masculine traits such as to raise the voice, being direct and rational. As opposite to Broverman et al. (1972), women stopped associating men to rational traits and women to emotional characteristics.

There are other factors influencing the glass ceiling phenomenon, such as selfconfidence of women (MARRA; BOGUE, 2006) and comparison to male colleagues (HAWKS; SPADE, 1998). Further studies covering other courses, besides the longitudinal effect, should explore how sexism affects women from different academic possible backgrounds. Curiously, on the private university studied, there are scholarships for students with the top ten GPA, in which this semester seven of them are women. Following the female 
students across their career path may help comprehending the non-academic barriers that prevent women to professionally ascend.

The feminist movement in Brazil, besides other social movements, should be incentivized in practical ways on university environments through the promotion of discussions aiming the personal development for both men and women. However, the association of the movement with political parties, specifically on the current polarized period in Brazil, makes it difficult to dialogue among the many groups of interest. Furthermore, this paper did not propose to interview men, considering they might manage their impressions not only by trying to respond questions accordingly to what is expected, but also considering the interviewer is a woman. At the same time, they could have an important role on feminist questions, understanding that they may also be benefited by feminist achievements such as paternity appreciation as fundamental on children' rising, or even the economy development as a whole.

The analysis of the data indicated that the gender differences do not go unnoticed in the academic environment and that, in fact, as pointed out by previous studies (BETIOL; TONELLI, 1991; SANTOS, 2002), women are discriminated against in this social dimension. Despite macho attitudes and comments, men, for the most part, do not perceive themselves as such. This behavior is usually transposed into lines that appear to be politically correct, uttered softly, or hidden under the mask of humor, which has shown that Brazilian national culture prevails over organizational cultures, even of European and North- American countries. Strictly speaking, the most relevant contribution of this research to the advancement of the discussion about gender discrimination in the work environment lies in the fact that it has discussed gender, not as a solid category, since, when it is interwoven with aesthetic issues, ethnic, social class and sexual orientation, the discriminatory process is accentuated, imposing on women second- or third-order discrimination.

When the gender package is opened we notice that other psychographic traits serve as a basis for discrimination even among women. When compared to other types of discrimination, gender-based violence proved to be peculiar. Unlike ethnicity, aesthetic sense and sexual orientation, which are attenuated when the individual belongs to favored social classes, as was suggested by the studies of Santos (1994), Ecco (2007) and Irigaray (2008), respectively, discrimination by genre is not mitigated under any circumstances. Thus women, even when rich, beautiful or hierarchically superior, continue to be discriminated against by men.

The implications of this study are for academia, organizations and society. As far as academia is concerned, it is up to researchers to recognize the multiple identities within seemingly hermetic categories and thus give voice to those silenced by social and organizational discourses. With regard to schools, it is the role of the administration and professors to implement practices that effectively curb discriminatory actions and harassment in the workplace. In relation to society, it is expected that it recognizes that, within its corpus, there are still individuals who have their citizenship kidnapped by social micro-practices. To embark on these implications seems to be an adequate suggestion for future research.

Despite all debate upon gender equity, in organizational and social studies, media or other forms of communication, it is not yet discussed in which ways it does really influence people's daily lives, especially women. The gap between discourse and practices might suggest why the results are not observable yet. Considering university as an environment of technical and personal transformation, managers should start concerning about what has been promoted in business school. After all, the educational environment is responsible to reproduce what occurs in society (FREIRE, 1987). 


\section{REFERENCES}

ALVES, M.; GALEÃO-SILVA, L. Crítica da gestão da diversidade nas organizações. Revista de Administração de Empresas, v. 21, p. 18-25, jul./set. 2004.

ARENDT, H. A condição humana. 10. ed. Rio de Janeiro: Forense, 2007.

ASKEHAVE, I.; ZETHSEN, K.K. Gendered constructions of leadership in danish job advertisements. Gender, Work and Organization. v. 21, n. 6, nov. 2014.

BAILY, J. Contemporary british feminism: opening the door to men? Social Movement Studies, v. 14, n. 4, p. 443-458, 2015.

BARBIERI, T. Sobre la categoría género. Una introducción teórico metodológica. In: AZEREDO, S.; STOCKLE, V. (org). Direitos reprodutivos. São Paulo: FCC/DPE, 1991. p. 24-45.

BAUMAN, Z. Identidade. Rio de Janeiro: Zahar, 2005.

BEAUVOIR, S. O segundo sexo: fatos e mitos. Rio de Janeiro: Nova Fronteira, 1995.

BECKER, H. Métodos de pesquisa em ciências sociais. São Paulo: HUCITEC, 1994.

BENHABIB, S. Situating the self. Gender, community and postmodernism in contemporary ethics. New York: Rotledge, 1992.

BETIOL, M. Ser administradora é o feminino de ser administrador? In: ENCONTRO DA ANPAD, 24., 2000, Florianópolis. Anais... Rio de Janeiro: ANPAD, 2000.

BETIOL, M.; TONELLI, M. A Mulher executiva e suas relações de trabalho. Revista de Administração de Empresas, v. 31, n. 4, out./dez. 1991.

BILLING, Y.D.; ALVESSON, M. Questioning the notion of feminine leadership: a critical perspective on the gender labelling of leadership. Gender, Work and Organization, v. 7, n. 3, jul. 2000.

BOJE, D. Stories of the storytelling organization: a postmodern analysis of Disney as “Tamara-Land". Academy of Mangement Journal, v.38, n. 4, p. 997-1035, 2001.

BOURDIEU P. A dominação masculina. Rio de Janeiro: Bertrand Brasil, 2007.

BOURDIEU, P.; MICELI, S. A economia das trocas simbólicas. São Paulo: Perspective, 1974.

BROVERMAN, I. et al. Sex-role stereotypes: a current appraisal. Journal of Social Issues, v. 28, n. 2, p. 59-78, 1972.

CARRIGAN, T.; CORNELL, B.; LEE, J. Toward a new sociology of masculinity. In: BROD, H. (Ed.). The making of masculinities. Boston: Allen and Unwin, 2002. 
CASOINIC, D. A. et al. Authentic leadership in the $21^{\text {st }}$ century: a closer look at the leader's discourse. In: GLOBAL CONFERENCE OF INTERNATIONAL HUMAN RESOURCE MANAGEMENT, 2., 2015, Pennsylvania State University. Anais... 2015.

CAVEDON, N.; FERRAZ, D. O reflexo do simbólico nas estratégias dos permissionários do viaduto Otávio Rocha. In: ENCONTRO DE ESTUDOS EM ESTRATÉGIA (3Es), 1., 2003, Curitiba: Anais... Curitiba: ANPAD, 2003.

CERQUEIRA, V. G. L. Extensão universitária, serviço social e movimentos sociais: a experiência do Núcleo Agrário Terra e Raiz da UNESP Franca/SP 1997/2007. 2015. 139f. Dissertação (Mestrado) - Programa de Estudos Pós-graduados em Serviço Social, Pontifícia Universidade Católica de São Paulo.

CHARAUDEAU, P.; MAINGUENEAU, D. Dicionário de análise do discurso. São Paulo: Contexto, 2004.

COSER, R. L. Reflections on feminist theory. In: WALLACE, R.A. (ed.) Feminism and sociological theory. Newburry Park, CA: Sage, 1989.

COSTA, A.A. O Feminismo "feminino" e a esquerda no Brasil. Revista feminismos, v.2, 2014.

CUNHA, B. Q. Antagonismo, modernismo e inércia: a política regulatória brasileira em três atos. Cadernos EBAPE.BR, Rio de Janeiro, v. 14, edição especial, jul. 2016.

DaMATTA, R. Carnavais, malandros e heróis. Rio de Janeiro: Rocco: 1979.

DEBERT, G. Problemas relativos à utilização da história de vida e história oral. In: CARDOSO, R. A aventura antropológica. Rio de Janeiro: Paz e Terra, 1986.

DELPHY, C. Feminismo e recomposição da esquerda. Estudos Feministas, Florianópolis, v. 2, n. 3, p. 187, jan. 1994.

DIJK, T. A. V. Principles of critical discourse analysis. Discourse and Society, v. 4, n. 2, p. 249-283, 1993.

EAGLY, A. H.; KARAU, S. Role congruity theory of prejudice toward female leaders. Psychological Review, v. 109, n. 3, p. 576-598, 2002.

EAGLY, A. H.; CARLI, L.L. "Women and the labyrinth of leadership". Harvard Business Review, p. 63-71, set. 2007.

ECCEL, C. S.; GRISCI, C. L. I. Trabalho e gênero: a produção de masculinidades na perspectiva de homens e mulheres. Cadernos EBAPE.BR, Rio de Janeiro, v. 9, n. 1, p. 5778, mar. 2011.

ECCO, U. História da feiúra. Rio de Janeiro: Record, 2007.

EUROPEAN INSTITUTE FOR GENDER EQUALITY. The involvement of men in gender equality initiatives in the European Union. Publications Office of the European Union, 2012. 
FLEURY, M. T. L. Gerenciando a diversidade cultural: experiências de empresas brasileiras. Revista de Administração de Empresas, São Paulo, v. 40, n. 3, p. 18-25, jul./set. 2000.

FOLEY, J. Effect of labeling and teacher behavior on children's attitudes. American Journal of Mental Deficiency, n. 83, p. 380-384, 1979.

FOUCAULT, M. Ditos e escritos. São Paulo: Galimard, 1994. v.4.

FREIRE, P. Pedagogia do oprimido. 17 ed. Rio de Janeiro: Paz e Terra, 1987. v.3.

GERGEN, K. The concept of self. New York: Holt, Rinehart \& Winston, 1991.

GOLDENBERG, M. A arte de pesquisar: como fazer pesquisa qualitativa em Ciências Sociais. 4.ed. Rio de Janeiro: Record, 2000.

GRANT THORNTON INTERNATIONAL BUSINESS REPORT 2016 - Women in business: transformando promessas em prática. Disponível em: <http://www.grantthornton.com.br/globalassets/_markets_/bra/media/arquivosindustrias/estudos/ gt_wib_turning_promise_into_practice_online.pdf $>$. Acesso em: 18 set. 2016.

GUIMARÃES, A. Como trabalhar com "raça" em sociologia. Educação e Pesquisa, v. 29, n. 1, p. 93-107, 2003.

HAWKS, B. K.; SPADE, J. Z. Women and men engineering students: anticipation of family and work roles. Journal of Engineering Education, v. 87, n. 3, p. 249-256, jul. 1998.

HIRATA, H. Nova divisão sexual do trabalho? Um olhar voltado para a empresa e a sociedade. São Paulo: Bomtempo, 2002.

IBGE. Censo demográfico 2010. Disponível em: <http://censo2010.ibge.gov.br/>. Acesso em: 18 set. 2016.

IRIGARAY, H. A. R. A diversidade nas organizações brasileiras: estudo sobre orientação sexual e ambiente de trabalho. 2008. 331f. Tese (Doutorado) - Escola de Administração de Empresas, Fundação Getúlio Vargas. São Paulo.

IRIGARAY, H. A. R.; PAIVA; K. C. M.; GOLDSCHMIT, C. C. Resiliência organizacional: proposição de modelo integrado e agenda de pesquisa. Cadernos EBAPE BR, Rio de Janeiro, v. 15, edição especial, p. 390-408, 2017.

IRIGARAY, H. A. R.; FREITAS, M. E. Sexualidade e organizações: estudo sobre lésbicas no ambiente de trabalho. Organizações \& Sociedade, v. 18, n. 59, p. 625-641, out./dez. 2011.

IRIGARAY, H. A. R.; VERGARA, S. C. O tempo como dimensão de pesquisa sobre uma política de diversidade e relações de trabalho. Cadernos EBAPE. BR, Rio de Janeiro, v. 9, n. 4, p. 1085-1098, dez. 2011.

IRIGARAY, L. Thinking the difference: for a peaceful revolution. New York: Routledge, 1994.

KANT, E. Anthropologie du point de vue pragmatique. Paris: Vrin, 1964. 
KIMMEL, M. S. Masculinity as homophobia: fear, shame and silence in the construction of gender identity. In: BROD, H.; KAUFMAN, M. (eds.) Theorizing masculinities. London: Sage, 1994. p. 213-219.

MACHADO, G. V., GALATTI, L. R.; PAED, R. R. Pedagogia do esporte e projetos sociais: interlocuções sobre a prática pedagógica. Movimento, Porto Alegre, v. 21, n. 2, p. 405-418, abr./jun. 2015.

MARCUSE, H. A ideologia da sociedade industrial. Rio de Janeiro: Zahar, 1973.

MARIUZZO, P.. Mulheres nas forças armadas desafiam conceito de soldado. Ciência e Cultura, São Paulo, v. 60, n. 4, p. 10-11, out. 2008.

MARRA, R. M.; BOGUE, B. Women engineering students' self efficacy - a longitudinal multi-institution study. In: WEPAN 2006 NATIONAL CONFERENCE PROCEEDINGS: BUILDING BRIDGES TO THE FUTURE ...FOR WOMEN IN ENGINEERING. 2006, Pittsburgh. Anais... 2006.

MIRANDA, A. R. A.; MAFRA, F. L. N.; CAPPELLE, M. C. A. Relações de gênero e poder: um estudo com professoras-gerentes em uma universidade pública. Revista Administração em Diálogo, São Paulo, v. 14, n. 3, p. 110-136, set./dez. 2012.

OLIVEIRA, D. M. A. S. Educação executiva e carreira: a contribuição do MBA brasileiro sob a ótica dos egressos. 2014. 130f. Dissertação (Mestrado Executivo em Gestão Empresarial) - Escola Brasileira de Administração Pública e de Empresas, Fundação Getúlio Vargas.

PRINGLE, R. Secretaries talk, sexuality, power and work. New York: Allen, 1988.

PUTNAM, L.; FAIRHURST, G. Discourse analysis in organizations: issues and concerns. In: JABLIN, J.; PUTNAM, L. (Eds.) The new handbook of organizational communication: advances in theory, research, and methods. Thousand Oaks, CA: Sage, 2001.

RICOEUR, P. O si-mesmo como um outro. Campinas: Papirus, 1991.

SANDBERG, S. Lean in: women, work, and the will to lead. Random House, 2013.

SANTOS, B. A construção cultural da igualdade e da diferença. In: SANTOS, B. A gramática do tempo: para uma nova cultura política. São Paulo: Cortez, 2002.

SANTOS, U. W. B. Métodos qualitativos para pesquisa em administração: caracterização e relacionamento aos paradigmas para pesquisa. 1994. 178f. Dissertação (Mestrado) Administração de Empresas, Pontifícia Universidade Católica do Rio de Janeiro.

SCHIFFRIN, D. Approaches to discourse. Oxford, UK: Blackwell, 1994.

SILVA, A. S. Marchando pelo arco-íris da política: a parada orgulho LGBT na construção da consciência coletiva dos movimentos LGBT no Brasil, Espanha e Portugal. 2006. 636f. Tese (Doutorado) - Programa de Estudos Pós-graduados em Psicologia Social, Pontifícia Universidade Católica de São Paulo.

STATI, S. Le transphrastique. Paris: PUF, 1990. 
STEIL, A. V. Organizações, gênero e posição hierárquica: compreendendo o fenômeno do teto de vidro. Revista de Administração, São Paulo, v. 32, n. 3, p. 62-69, 1997.

TONELLI, M. J. A Questão das relações amorosas e familiares. In: DAVEL, E.; VERGARA, S. C. Gestão com pessoas e subjetividade. São Paulo: Atlas, 2001. p. 213-234.

UNITED NATIONS. The role of men and boys in achieving gender equality. New York: Author, 2004.

VICKERS, M. Illness, work and organization: postmodern perspectives, antenarratives and chaos narratives for the reinstatement of voice. Journal of Critical Postmodern Organization Science, v. 3, n. 2, p. 74-88, 2005.

WALKER, N.A., MELTON, E.N. The tipping point: the intersection of race, gender, and sexual orientation in intercollegiate sports. Journal of Sport Management, v. 29, n. 3, p. 257-271, 2015.

WALUMBWA, F. O. et al. Authentic leadership: development and validation of a theorybased measure. Journal of Management, v. 34, n. 1, p. 89-126, out. 2008. 